\title{
Balanced Housing Development in Yogyakarta, Indonesia-Policy, Reality, and Problem
}

\author{
Hastuti Saptorini \\ Architecture Department, Faculty of \\ Civil Engineering and Planning \\ Universitas Islam Indonesia \\ Yogyakarta, Indonesia \\ 885120102@uii.ac.id
}

\author{
Nur Rahmah Tri Utami \\ Management Department, Faculty of \\ Business and Economics \\ Universitas Islam Indonesia \\ Yogyakarta, Indonesia
}

\author{
Mahditia Paramita \\ Housing Research Center \\ Yogyakarta, Indonesia
}

\begin{abstract}
The planned housing has been phenomenally developed in some big cities in Indonesia, included Yogyakarta. The housing has been built in various models as government's policy for getting equity in diversity and for reducing housing backlog in Indonesia. The housing policy that is relevant to the problem is Balanced Housing Development. This policy has been undergone adjustments in several decades which in principle aim to alleviate the Developers in implementing this policy. The policy began with the establishment of a balance of luxury quality housing development: moderate; simple $=1: 3$ : 6 to 1: 2: 3. The developers still had difficulty for implementing. The fact shows that the implementation of balanced residential based housing development in Yogyakarta was still very low, which is only $1,22 \%$. By using the data research group of "Income Generation in The Planned Housing Development" funded by High Directorate Education National Department, and some actually relevant articles, this paper discusses of what is the problem of the low achievement of the balanced ratio. Some observers of housing development and housing developers have discussed a lot of the lack of achievement on the policy. But the fundamental causes of the lack of achievement have not been studied in depth. On this basis, this paper aims to examine the causes of the low achievement and what are the solution strategies. Conclusion indicates that there are five obstacles for implementing the regulations: land prices, housing regulations, housing development authorities, community conditions, and developers as housing businesses. The solution strategies may be to evaluate the housing standards, applying progressive concepts to land ownership, determining the allocation of land for MBR in the land use regulation, and to incentives and disincentives for housing developers.
\end{abstract}

Keywords - land price, low achievement, land use regulation

\section{INTRODUCTION}

The regulation on balanced housing development has long been rolled out by the Government. The main objective is to overcome housing backlog that has never been polluted. In addition, this overcomes to all levels of society having equal access to settlements [1]. This regulation was promulgated in 1992 [2] through a Joint Decree (SKB) of 3 Ministers (Minister of Home Affairs, Minister of Public Works, and Minister of Public Housing) with a balance ratio of luxury housing units: moderate: simple $=1: 3: 6$. This regulation seems not easy to realize.

In 2013 the Minister of Housing Regulation No. 7 of 2013, which rationalized the balance comparison to $1: 2: 3$
[3]. But the achievement of the realization is also not very significant. Yogyakarta's experience in realizing balanced residential development only reached $1.22 \%$ of the 492 Developers surveyed [4]. The hope of building a number of simple housing units as a consequence of balancing the construction of luxury and medium units for Housing Development Actors, was apparently not easy to implement. Government also affirmed this with the regulation of Republic of Indonesia No 14 of 2016 regarding housing and settlement area Article 11 paragraph 3 which reads: housing planning includes simple houses, medium houses, and/or luxury homes [5]. But the achievement of the implementation of the regulation was not significant.

A number of observers of housing development have examined the causes, both in terms of engineering, architecture, and law. The actors who studied were also from various stakeholders, both Housing Development Actors, bureaucrats, and academics. All contributed thoughts, arguments, and even hypotheses regarding the low achievement of the implementation of this regulation. The author tries to link the findings of research conducted several years ago with observers' notes on housing development regarding the implementation of balanced residential development. So the purpose of this paper is to find the constraints that are indicated as causes / reasons for the low implementation of balanced residential development, with the Yogyakarta case study.

\section{LITERATURE REVIEW}

\section{A. Balanced Housing Development Regulation}

Implementation of the principle of residential development with balanced residential set by the government based on Regulation No. Housing Minister 10 Year 2012 on Implementation of the Housing and Residential Settlement Region Balanced. The rules are the guidelines for the Government, Provincial Government, District/city and every person in the administration of housing and settlements with a balanced residential area.

Balanced residential regulation is done by the foundation based on policy and philosophical foundations. Implementation of regulatory policy platform is balanced residential Act No. 1 of 2011 on housing and residential areas, which are described therein, which in article 34 , 
2. Fulfilment of the requirements for all Indonesian People (Amendment of Article 28 of the 1945 Constitution $\mathrm{H}$ ).

Article 34:

1. Entity conducting residential development shall achieve balanced residential housing with.

2. Large-scale housing development undertaken by legal entities are obliged to realize balanced residential in one stretch.

3. Obligations referred to in paragraph (1) to legal entities which are exempt residential building which is entirely devoted to meeting the needs of the general.

4. In terms of residential development referred to in paragraph (1), the Government and / or the local government can provide incentives to encourage For legal entities with balanced residential housing development.

Article 35:

1. Large-scale housing development with a balanced residential home includes a simple, medium-sized homes, and luxury homes

2. Provisions regarding balanced residential governed by Minister

Article 36:

1. In terms of residential development with a balanced residential not in one stretch, public housing should be implemented in the Regency/City.

2. Public house construction as defined in paragraph (1) shall have access to the service centre or workplace 3 Ease of access referred to in paragraph (2) shall be regulated by local regulation.

3. Balanced residential housing development referred to in paragraph (1) shall be conducted by the same legal entity

Article 37:

Further provisions on balanced residential regulated by Ministerial Regulation.

As for the philosophical foundation consists of an assessment of the aspects: socio-culturally, socio justice, and economic-justice.

Socio-cultural Aspects:

1. Inhabited by people of various professions, levels of economic and social status.

2. Based on a sense of community, kinship, mutual cooperation, and social solidarity.

3. Avoid residential groupings that can drive social vulnerability.

Social Justice Aspects:

1. Realize the 5th of Pancasila, namely social justice for all Indonesian people in the field of housing.
Economic Justice Aspects:

1. Housing or residential area that was built in a harmonious and balanced between the simple, medium-sized homes, and luxury homes.

2. Improve people's welfare and equity.

3. Increase regional economic growth.

The purpose of the implementation of these regulations is balanced residential ensure the availability of luxury homes, intermediate, and simple (one plot or not a stretch), achieve harmony among groups of people (Profession, economic and social status), to realize cross-subsidies (Financing, Management), creating harmony living place (socially and economically), and Land Utilization efficiency.

In the administration of housing and residential areas by using the principle of balanced residential has several requirements, namely requirements of the location and composition requirements. Location requirements, balanced Use development in terms of the stretch can be used to realize the construction of residential areas, residential environment, housing, and housing. As for the requirement of development not only in one plot can be used to build housing.

Composition requirements, these requirements consist of requirements and the requirements of the vast amount of land. To the requirements of the number of houses, in Article 9 states that residential development, the composition used is 1:2:3 where 1 section for luxury homes, second homes section for medium, and 3 parts for a modest home. The composition of the comparative figures only minimal numbers. In doing so, developers can adapt to the conditions of each region. The next requirement is the area of land. In housing construction in one stretch, required that $20 \%$ of the land area should be used for the construction of a modest home. To achieve the success of the balanced residential, multiple stages of planning, development, and control must be done in a responsible manner.

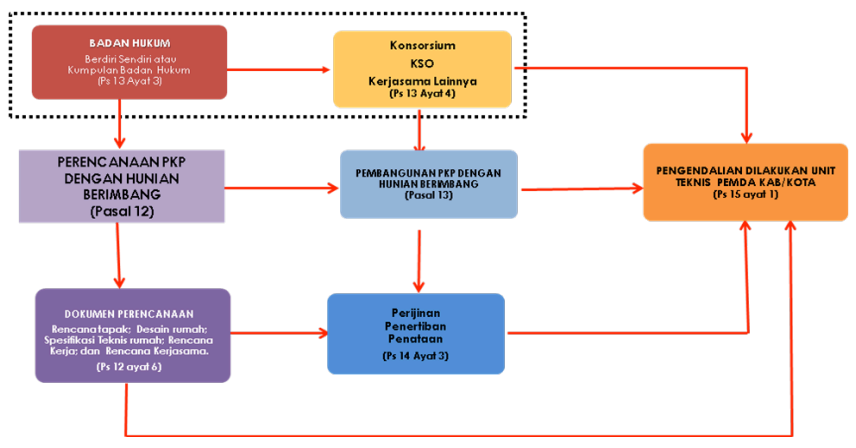

Fig. 1. Chart Planning, Development and Control in the Implementation of the Housing and Settlement in Principle Residential Zone Balanced. (Source: Socialization Area Development Policies for Fiscal Year 2012) residential location can be in one plot and not in one stretch. 
land costs to housing prices is indeed relative, depending on several factors. First is related to location factors. The more strategic the location of the land, the higher the price. Land location is said to be strategic, if it is located in the center of the city or in an area that is potentially a city (the center of city activity). Second is the level of maturity and land readiness for buildings. Land is said to be mature, can be seen from two sides: legality and physicality. Land is ripe legally, if it is certified, the status of ownership, and the status of land use as a yard. The land is physically mature, if the conditions are already harsh, the road is relatively wide and has a paved / built surface and is equipped with drainage systems and road equipment such as lighting, garbage bins, etc.

Although the allocation of land prices to houses is relative, from the experience of a number of housing developers / builders, at least the cost of land absorbs 50\% of the house price. This means that the portion of land costs to home prices is relatively significant. So when land prices are high and dynamic, house prices skyrocket. This has become problematic for low income people (MBR) considering that the increase in MBR income is not as high / unable to compensate for rising house prices. In other words, the purchasing power of the MBR is decreasing. Purchasing power in housing study theory is called affordability. Affordability is determined by three parameters: cost, income, and rent [7]. Cost is the price of housing which is determined by six factors: land, finance, infrastructure, labor, materials, and regulation. Income is the earner's family which is also used to determine in spending money for housing. Rent is the parameter which is related / manifested to the saving capacity.

\section{METHOD}

While the Minister for Housing Regulation No 10/2012, the definition of the limits described luxury homes, medium homes, and modest houses are as follows:

\section{a. Simple homes}

The house is a modest public house built on land plots with an area of between $60 \mathrm{~m} 2$ to $200 \mathrm{~m} 2$ with a floor area of at least $36 \mathrm{~m} 2$ building with a selling price according to government regulations.

\section{b. $\quad$ Medium Homes}

The house is a medium-sized commercial houses with a selling price greater than 1 (one) to 4 (four) times the price of a modest home.

\section{c. Luxury homes}

Luxury homes are selling at a price of commercial houses is greater than 4 (four) times the selling price of a modest home.

\section{Elements of Housing Development Financing and Affordability}

Theoretically, the cost of housing construction consists of 2 main elements. First is the cost to purchase land, and second is the cost to construct the house. The allocation of

\section{A. Data Gathering and Analysis}

The data and study material are collected from 3 recourses. Those were the results of previous Authors' researches, publications on balanced residential development studies, and some relevant housing development theories. which were enriched with relevant publications. The previous Authors' researches location conducted in some planned housing developments in Yogyakarta Special Province. Enriching data is collected through the relevant secondary data.

\section{B. Discussion Mechanism}

The discussion is analyzed by linking the findings of the research that has been done, with the findings of the study of similar topics, and the theoretical parameters of housing development. The findings of the research that have been carried out indicate a picture of the reality of the realization of balanced residential development, in the form of planned residential developments that were focused on mass housing constructed and planned by developers, both public and private. Mass scale is intended as a development model that offers various categories of housing units. The findings of similar topic studies are secondary data obtained from the 


\section{Housing Composition}

The composition of housing development in Yogyakarta is dominated by the unbalanced housing development.

TABLE I. LEVEL OF BALANCED HOUSING DEVELOPMENT optimize the results of the balanced housing development and their sustainability. Diagrammatically, the method can be seen in Figure 1.

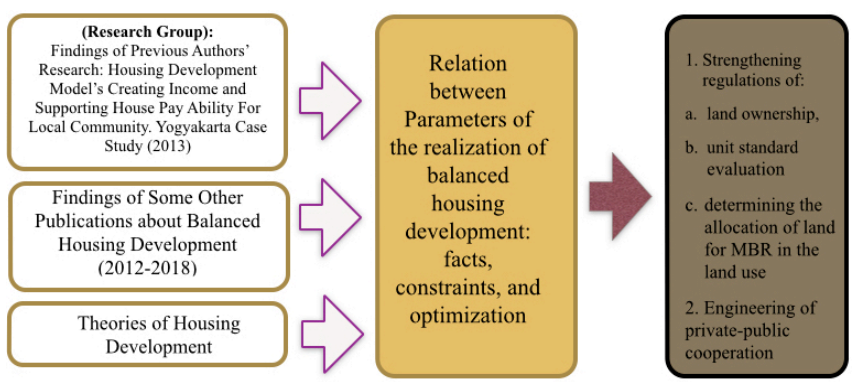

Fig. 2. Method of Discussion

\section{DATA AND DISCUSSION}

\section{A. Policy Implementation: research result}

Spirit of the government to promote balanced development of housing actually has a policy platform and a philosophical foundation that is strong enough and clear. The foundation of the policy set forth in section 4 (34-37) at Law No. 1/2011 is nuanced "force" housing development actors incorporated to build the type of housing units in proportion to the modest quality, moderate, and luxury. This policy, among others, is to provide a cross-subsidy for low income people.

Planned residential builder experience in Special Region of Yogyakarta (DIY) in implementing this policy seems to have not been fully implemented. The study found that of 492 builders (Fig.2), not more than $2 \%$ adherent implement this policy. There are just $1,22 \%$ developers who build the type of houses with balanced proportion (Table.1). It was means that there just 6 developers, in DIY, which have already implemented the balanced housing development.

\section{B. Housing Location Distribution}

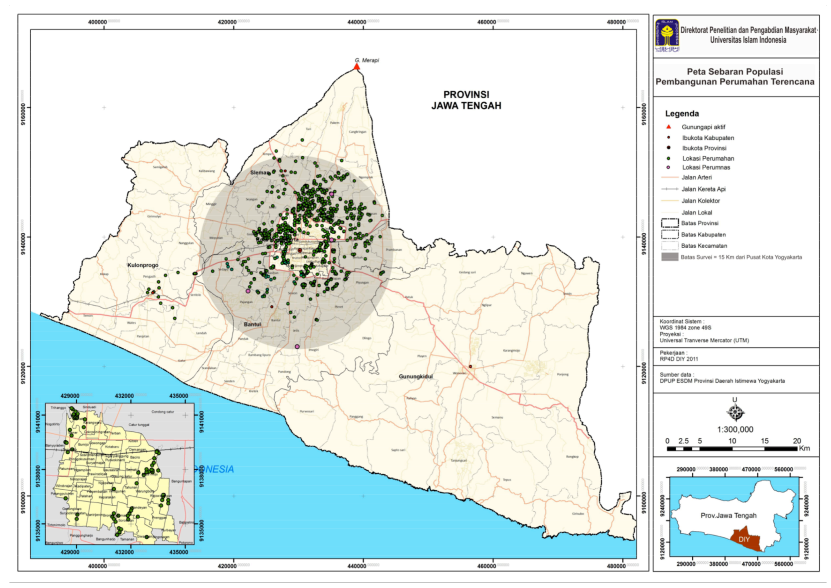

Fig. 3. Housing Development Distribution in DIY

\begin{tabular}{|c|c|c|c|c|c|}
\hline \multirow{2}{*}{$\begin{array}{c}\text { Level of } \\
\text { Balanced } \\
\text { Housing } \\
\text { Type }\end{array}$} & \multirow{2}{*}{\multicolumn{2}{|c|}{ Composition }} & \multicolumn{2}{|c|}{ Housing Complex } & \multirow{2}{*}{$\begin{array}{l}\text { Name of } \\
\text { Developers }\end{array}$} \\
\hline & & & $\begin{array}{c}\text { Number } \\
\text { (Developers) }\end{array}$ & $\%$ & \\
\hline Balanced & \multicolumn{2}{|c|}{$\begin{array}{l}\text { Modest/simple, } \\
\text { medium, and } \\
\text { luxury }\end{array}$} & 6 & 1,22 & $\begin{array}{l}\text { Bangunjiwo } \\
\text { Sejahtera, } \\
\text { Graha } \\
\text { Nirmala, } \\
\text { Griya } \\
\text { Baiturahman, } \\
\text { Samara } \\
\text { Regency, } \\
\text { Satria } \\
\text { Nusantara, } \\
\text { Tiara Mas } \\
\text { Wonocatur. } \\
\text { Semua } \\
\text { berlokasi di } \\
\text { Kab. Bantul }\end{array}$ \\
\hline \multirow[t]{3}{*}{$\begin{array}{l}\text { Semi } \\
\text { Balanced }\end{array}$} & 1 & $\begin{array}{l}\text { Modest, } \\
\text { medium }\end{array}$ & 38 & 7,72 & \multirow[t]{3}{*}{18,49} \\
\hline & 2 & $\begin{array}{l}\text { Modest, } \\
\text { Luxury }\end{array}$ & 4 & 0,81 & \\
\hline & 3 & $\begin{array}{l}\text { Medium and } \\
\text { Luxury }\end{array}$ & 49 & 9,96 & \\
\hline \multirow[t]{3}{*}{ Unbalanced } & 1 & Modest/Simple & 162 & 32,93 & \multirow[t]{3}{*}{80,29} \\
\hline & 2 & Medium & 163 & 33,13 & \\
\hline & 3 & Luxury & 70 & 14,72 & \\
\hline \multicolumn{3}{|l|}{ Total } & 492 & \multicolumn{2}{|c|}{100} \\
\hline
\end{tabular}


caused by 5 indicative factors, namely issues / constraints that indicate obstacles. Five factors that confront these obstacles are: 1) land prices, 2) housing regulations, 3) housing development authorities, 4) community conditions, and 5) Developers as housing businesses.

The first indicative factor as the strongest reason is skyrocketing land prices. The increasing demand for land for settlements, while the use of land for settlements is relatively minimal. The reason land prices in Yogyakarta skyrocketed [5]. The reason is that the demand for land for residences in Yogyakarta is growing all the time. In the past 3 years, land prices have ranged from 1.5 million to 25 million per square meter. Yogyakarta as a city of students and tourism is an attractive place, comfortable, and has a high life expectancy. This has resulted in many investors wanting to invest, so land demand increases while the supply is static.

This increase in land prices will greatly affect housing prices. Half or about $50 \%$ of production costs for land allocation [1]. Thus, when land prices are high, residential prices are also high, and consequently even simple house prices.

The second indicative factor/issue is the presence of 3 housing regulation points which are considered not yet compatible with current housing development conditions, namely related to a) land standards, b) derivatives of Central-Regional regulations, and c) disincentives. Some housing observers consider the land standard for housing units specified in the Minister for Housing Regulation No $10 / 2012$ to require evaluation because it is considered relatively high. He stated that a modest public house was built on land plots with an area of between $60 \mathrm{~m} 2$ to 200 $\mathrm{m} 2$. Middle homes that are built on land and plots of 200$600 \mathrm{~m} 2$, and the luxurious home are built on land and plots of $600-2,000 \mathrm{~m} 2$. The large size of the standard land automatically reduces the number of units produced by the Developer, so that the spirit of increasing housing stock is reduced and the spirit of dissolving housing backlog is relatively insignificant.

Derivation of the issuance of the Central Regulation to Regional Regulations related to balanced housing is seen by some housing observers as not yet fully welcomed [8][9][10]. The slow implementation of balanced housing was because it was very dependent on the Regional Government (Pemda) as a guide and coordinator as well as the formulation of policy implementation [10]. When the development actors are consequently of the $20 \%$ allocation for the MBR that is allowed not in one overlay, then the local government should already have a regulation on the location of housing construction for the MBR. In practice, not all Local Governments have prepared housing construction sites for this community. Moreover, this substance is taken into consideration in granting licenses that are the authority of the Regional Government.

Another obstacle related to regulation is the readiness of infrastructure in the residential environment. The availability of drainage infrastructure in residential land is relatively not ready / mature. As a result, housing builders Substantially, the factors indicated as causes of the low implementation of balanced residential development are 
TABLE III. OBSERVERS' NOTES / HOUSING STAKEHOLDERS OF THE IMPLEMENTATION OF BALANCED RESIDENTIAL DEVELOPMENT

must allocate large costs for infrastructure including drainage.

The issue of incentives has also not been felt by the Housing Builders. Problems of taxation, licensing, and other administrative procedures are also awaited by the Developers to accelerate and motivate housing development [9]. During this time, the issue of energy, time, and cost to take care of this problem has also become an obstacle for Developers to motivate and add to their long chain of problems in preparing a simple house as a counterweight.

The authority capacity in overseeing the implementation of balanced housing regulations is also not yet significant. The disincentives for Developers who have not demonstrated the implementation of balanced housing have not been acted upon and recorded in the public sphere. In fact, the phenomenon of "retail" finished houses being sold in Yogyakarta is very widespread. Developers only build a very minimal number of units, 2-5 units, often found in many locations. Thus the demands for implementing balanced housing regulations cannot be imposed on them. Many housing observers noted this phenomenon. The law enforcement on the implementation of this regulation is not yet significant [1][1][8][11][12] .

The fundamental obstacle that is still legendary is the low purchasing power / affordability of MBR in buying a home. The increase in MBR salaries, especially those with the Regional Minimum Wage standard, has only increased from year to year as a series of calculations. Meanwhile, house prices have risen like a series of measurements. It is undeniable that house prices have risen sharply because land prices, which absorb $50 \%$ of home prices, have skyrocketed without control. Based on the theory, affordability of buying a house is determined by 3 elements, namely salary / income, house prices, and the ability to rent / savings / repayments. Thus, when the MBR salary increase is not significant, the necessities of life are still relatively high due to high inflation, the ability of the ability to rent / savings / repayments will also decrease. Plus worse, housing prices skyrocket. Thus, the probability of buying a house for the MBR, even for a modest house, is getting worse.

The paradigmatic constraint, it turns out, is also noted by observers of housing. The view that occupancy regulations are balanced, is perceived as a form of shifting responsibility from the Government to the Developer [11]. The balanced housing scheme gives the impression as if the government is throwing the responsibility on the developer to provide housing for the people [13]. This opinion arises because the government has not prepared clear incentives. In addition, at present the price of land has been released to the market as a result of uncontrolled land price increases. The high price of land makes it difficult for developers to prepare a certain portion of land for the construction of simple houses whose price has been determined, while the price of the land itself is almost close to the price of the predetermined modest house. In fact this view can be ignored if the Government shows its sincerity in managing regulations and overseeing its implementation comprehensively. In summary, the five indicative factors are summarized and categorized in the following Table 3.

\begin{tabular}{|c|c|c|}
\hline $\begin{array}{l}\text { Indicative } \\
\text { Factors }\end{array}$ & Study / Description & Sources \\
\hline Land & $\begin{array}{l}\text { Land prices skyrocket } \\
\text { due to demand far } \\
\text { higher than supply; } \\
\text { release of land prices to } \\
\text { the market so that it is } \\
\text { not controlled. }\end{array}$ & $\begin{array}{l}\text { Ratnasari (2016); } \\
\text { Maharso (2014); } \\
\text { Probondaru } \\
\text { (2018); }\end{array}$ \\
\hline \multirow{3}{*}{$\begin{array}{l}\text { Housing } \\
\text { Regulation }\end{array}$} & $\begin{array}{l}\text { The land standard for } \\
\text { each unit is too large } \\
\text { (Constitution/UU) }\end{array}$ & Triyuly (2013) \\
\hline & 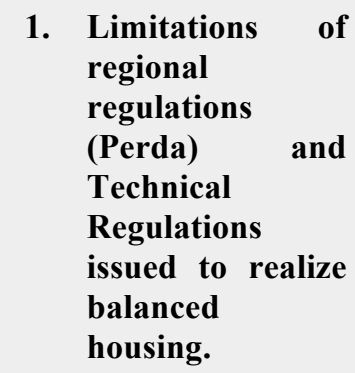 & 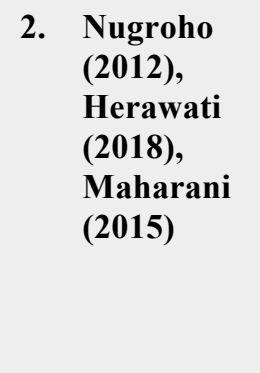 \\
\hline & $\begin{array}{l}\text { Tax incentives, } \\
\text { certification, location } \\
\text { of simple houses / } \\
\text { flats have not been } \\
\text { significant }\end{array}$ & $\begin{array}{l}\text { Fahmiarto } \\
\text { (2011); Maharani } \\
\text { (2015); } \\
\text { Kristarani } \\
\text { (2018), Japardi } \\
(2018)\end{array}$ \\
\hline \multirow[t]{2}{*}{ Authorities } & $\begin{array}{l}\text { Development } \\
\text { supporting } \\
\text { infrastructure for } \\
\text { settlements has not } \\
\text { been evenly } \\
\text { distributed to reduce } \\
\text { house prices (road } \\
\text { infrastructure, } \\
\text { drainage, permits, } \\
\text { etc.) }\end{array}$ & $\begin{array}{l}\text { Ratnasari (2016); } \\
\text { Maharani (2015); } \\
\text { Kristarani (2018) }\end{array}$ \\
\hline & $\begin{array}{l}\text { Law enforcement is not } \\
\text { yet significant. }\end{array}$ & $\begin{array}{l}\text { Mungkasa } \\
\text { (2013); } \\
\text { Yoswiarto (2014) }\end{array}$ \\
\hline Community & $\begin{array}{l}\text { MBR purchasing power } \\
\text { is low }\end{array}$ & Redaksi (2012) \\
\hline Developers & $\begin{array}{l}\text { 3. View as a form } \\
\text { of shifting } \\
\text { responsibility }\end{array}$ & $\begin{array}{l}\text { Mungkasa } \\
\text { (2013); } \\
\text { Probondaru } \\
\text { (2018) }\end{array}$ \\
\hline
\end{tabular}




\section{The Affordability}

The purchasing power of houses for the MBR, until now, is still a problem. The low affordability required MBR capacity building engineering. Community development that stimulates and provides opportunities for MBR to create and boost revenue is a strategy that must be developed. Economic stability with minimal inflation is a condition that needs to be conditioned so that MBR income is not sucked up for the needs of routine living, and can increase the saving / set aside some funds for the benefit of the board.

\section{CONCLUSIONS}

Implementation of balanced housing regulations involves a number of actors / actors in the development of housing in a comprehensive and systemic manner. On the other hand, strengthening the regulations governing operations still needs improvement and strengthening in several aspects to minimize the constraints as indicated by the indicative factors. Prioritized and structured, the following 5 points are conclusions that can be recorded and acted upon to maximize the achievements of implementing balanced housing.

The experience of implementing balanced residential development in Bantul should be appreciated and used as best practice to induce other Developers.

Increasing the presence and sustainability of the relationship between the Central and Regional Governments in developing and overseeing the regulation of balanced housing is very much needed to harmonize the spirit and aspirations of resolving the housing backlog issue significantly.

Strengthening regulations to dissolve several indicative factors needs to be prioritized. Starting from evaluating housing standards, applying progressive concepts to land ownership, determining the allocation of land for MBR in the land use regulation, to incentives and disincentives for housing developers.

The engineering of private-public cooperation in executing balanced residential development is constantly updated, evaluated, and innovated to build harmony in mutualistic symbiosis.

Strengthening awareness for developers in terms of conception of sustainable work through balanced and proportional understanding of socio-economic-cultural values. That is, Developers are not only profit oriented, but social values are built up and internalized. Thus, the hope that corporate responsibility in setting aside some profit for social interests is not forgotten but is seen as an inherent obligation for Developers. Sustainable housing should ensure a better quality of life, not just now but for future generations as well. It should combine protection of the environment, sensible use of natural resources, economic growth and social progress [14]. purchasing power of low-income people. 


\section{ACKNOWLEDGMENT}

The research that initiated this paper came from the Research and Technology Department of Higher Education through the Competitive Grants program. For that, many say thanks. Hopefully this study will add to the treasure of knowledge of housing development in Indonesia.

\section{REFERENCES}

[1] H. Kristarani, 2018, "Implementasi Hunian Berimbang Di Kota Yogyakarta". https://www.researchgate.net/publication/324654683, 2018.

[2] Ministry of Public Housing, "Joint Decree (SKB)of 3 Minister (Minister of Home Affairs, Minister of Public Works, and Minister of Public Housing), Jakarta, 1992.

[3] Ministry of Housing Regulation, Permen 7/2013, Jakarta, 2013.

[4] H. Saptorini, N.R.T.Utami, M.Paramita, "Housing Development Model's Creating Income and Supporting House Pay Ability For Local Community. Yogyakarta Case Study, Dikti Final Research Report, Unpublished, 2013.

[5] Y. Ratnasari , Harga Tanah Mahal, Media Online, https://tirto.id/q/harga-tanah-mahaleCF?utm_source=Tirtoid\&utm_medium=Lowkeyword

[6] S. Maharso, "Aturan Baru Hunian Berimbang Sulit Dijalankan", Munas REI XIV Dewan Pengurus Pusat Persatuan Perusahaan Real Estate Indonesia, Jakarta, 2014

[7] Mayo, "Housing Enabling Markets To Work With Technical Supplements": A World Bank Policy Paper, The International Bank for Reconstruction and Development The World Bank, USA, 1993

[8] S.Maharani, Pembangunan Perumahan Dengan Hunian Berimbang Bagi Pemenuhan Kebutuhan Rumah Untuk Masyarakat Berpenghasilan Rendah, Jurnal Penelitian Hukum Legalitas Volume 9 Nomor 1, Mei - Oktober 2015, ISSN. 1411-8564, hh. 41- 50, 2015.

[9] A. Fahmiarto, "Hunian Berimbang: Antara Teori Dan Realita", INFORUM. Media Komunikasi Komunitas Perumahan. Edisi II: Jakarta., 2011

[10] E.A. Nugroho, Hunian Berimbang Sulit Direalisasikan, Investor Daily Indonesia, 9 Agustus 2012,

[11] O. Mungkasa, Catatan Kritis tentang Hunian Berimbang, HUDSMagz, Edisi 4, https://www.academia.edu/4893718/Catatan_Kritis_tentang_Hunian_ Berimbang, 2013.

[12] A.E.Yoswiarto, Arkial Eko, "Distribusi Penerapan Peraturan Menteri Perumahan Rakyat No. 10 Tahun 2012: Studi Ekonomi Politik Pembangunan Perumahan Di Kota Surabaya", Jurnal Politik Muda, Vol. 3 No. 3, Agustus-Desember 2014, 344-356, 2014.

[13] I.P. Probondaru, Problematika Pelaksanaan Hunian Berimbang di Indonesia, 2018. [14] E. Brian, "Sustainable Housing. Principle \& Practice.E \& FN Spon. Francis and Taylor Group Publisher: London, 2005 